\title{
RESPON MAHASISWA TERHADAP KULIAH KERJA MAHASISWA PROGRAM KREATIFITAS MAHASISWA (KKM PKM) SAAT PANDEMI COVID-19
}

\author{
Ma'ulfi Kharis Abadi ${ }^{1}$, Mutiah ${ }^{2}$ \\ ${ }^{1}$ Teknik Sipil, Universitas Banten Jaya Jl. Ciwaru II No. 73 Kota Serang, Banten, Indonesia \\ ${ }^{2}$ Pendidikan Masyarakat, Universitas Ibn Khaldun Bogor, Jl. Sholeh Iskandar, Kota Bogor, Jawa Barat \\ Email: maulfikharisabadi@unbaja.ac.id
}

\begin{abstract}
Community Development Participation (KKM) is a compulsory subject that must implemented by students. In 2020 the Covid 19 pandemic occurred with transmission through droplets from sufferers so that to cut the risk of contracting, you must keep your distance. The government issued a regulation large scale social restrictions (PSBB) in handling Covid 19 which contained no gathering/physical distance. KKM must implemented without going to the society. KKM 2020 implemented with the KKM PKM concept where KKM participants make PKM proposals. This research conducted at the Universitas Banten Jaya during implementation of the KKM PKM. The questionnaire was given to respond to assignment of field supervisors, individual assignments, PKM group assignments and KKM large group assignments. KKM PKM can run well seen from the duties of the field supervisor lecturers and the tasks of the participants carried out well. There were KKM participants who dissatisfied with participating in the KKM PKM. This PKM KKM study can used as material for improvement so that the KKM program is carry out well, according to the goals and the participants are satisfy.
\end{abstract}

Keywords: Covid 19; KKM; PSBB.

\begin{abstract}
ABSTRAK
Kuliah Kerja Mahasiswa (KKM) merupakan matakuliah wajib yang harus dilaksanakan oleh mahasiswa. Tahun 2020 terjadi pandemi Covid 19 dengan penularan melalui percikan-percikan (droplet) dari pederita sehingga untuk mengurangi resiko tertular harus menjaga jarak. Pemerintah mengeluarkan aturan pembatasan social bersekala besar (PSBB) kdalam penanganan Covid 19 yang berisikan dilarang berkumpul atau jaga jarak. KKM harus dilaksanakan tanpa terjun ke masyarakat. KKM 2020 dilaksanakan dengan konsep KKM PKM dimana peserta KKM membuat proposal PKM. Penelitian ini dilakukan di Universitas Banten Jaya pada saat pelaksanaan KKM PKM. Kuesioner yang diberikan untuk menanggapi tugas dosen pembimbing lapangan, tugas individu, tugas kelompok PKM dan tugas kelompok besar KKM. KKM PKM dapat berjalan baik dilihat dari tugas dosen pembimbing lapangan dan tugas peserta dilaksanakan dengan baik. Terdapat peserta KKM yang merasa tidak puas mengikuti KKM PKM. Kajian KKM PKM ini dapat dijadikan bahan untuk perbaikan sehingga program KKM terlaksana dengan baik, sesuai tujuan dan peserta merasa puas.
\end{abstract}

Kata Kunci: Covid 19; KKM; PSBB.

\section{PENDAHULUAN}

Kuliah Kerja Mahasiswa (KKM) adalah matakuliah wajib di berbagai Universitas. KKM adalah matakuliah yang berfungsi sebagai wadah mahasiswa dalam pengabdian kepada masyarakat sesuai tri dharma perguruan tinggi. Pelaksanaan KKM umumnya dilaksanakan selama 1 bulan pada akhir semester genap. Mahasiswa melaksanakan KKM dengan ditempatkan di kampung-kampung dan bergabung dengan masyarakat (Renaldi et al., 2013). KKM ini kegiatan yang dilakukan oleh mahasiswa dengan tujuan agar mahasiswa itu sendiri bisa 
bermasyarakat dan mampu mengimplementasikan ilmu yang sudah didapatkan dibangku kuliahan (Perdana et al., 2013). Mahasiswa membaur dengan masyarakat dan menganalisis permasalahan atau mencari hal yang perlu diperbaiki. Setelah mahasiswa menemukan suatu permasalahan selanjutnya mencari berbagai pemecahan masalah yang paling tepat. Penyelesaian dilakukan atau diinisiasi oleh mahasiswa secara berkelompok atau saling berbagi tugas. Kemampuan siswa dapat ditingkatkan dengan pembelajaran mandiri dan pembelajarn secara tim (Su \& Hu, 2020). Cara KKM berkelompok dan membaur dengan masyarakat seperti ini adalah cara yang lumrah dan biasa dilakukan dalam KKM. KKM tahun 2020 mengalami perbedaan karena pada KKM terjadi wabah pandemi Covid 19.

Covid 19 adalah virus yang menyebar pertama kali di Wuhan-Cina. Covid 19 termasuk virus yang banyak memakan korban jiwa. Covid 19 menyerang saluran pernapasan dengan diagnosis gejala umum demam, batuk dan sulit bernafas (Yuliana, 2020). Sesak nafas yang diakibatkan Covid 19 dapat mengakibatkan kematian. Seiring perjalanan waktu, penderita covid tidak selalu nafas dan mati rasa pada indra perasa sehingga tidak dapat beraktivitas dengan normal. Terdapat penderita covid 19 yang tidak mengalami gejala atau disebut orang tanpa gejala (OTG). OTG ini sulit dideteksi karena tidak mengalami gejala seperti umum tetapi membawa covid 19 tetapi OTG dapat menularkan covid 19. Covid 19 menular melalui cairan tubuh atau berupa percikan-percikan (droplet) dari penderita yang menyebar di sekitar penderita lalu masuk ke dalam tubuh orang lain (Athena et al., 2020). Cara penularan virus melalui droplet yang melayang menjadi hal yang riskan terjadi ketika banyak orang-orang berkumpul. Pemerintah dalam penanganan penyebaran dan penularan covid 19 menyarankan untuk tidak berkumpul dengan melakukan jaga jarak (social distancing). Pemerintah juga mengeluarkan berbagai peraturan terkait PSBB yang salah satunya dilarang berkumpul. Menanggapi aturan PSBB dari pemerintah, Universitas Banten Jaya (Unbaja) mengeluarkan peraturan yang salah satunya kegiatan KKM tidak boleh berkumpul dan tidak boleh membaur dengan masyarakat. Larangan berkumpul ini menjadi dasar bagi panitia KKM bahwa KKM 2020 tidak boleh berkumpul dan membaur dengan masyarakat. Panitia KKM Unbaja melakukan berbagai inovasi yang cocok untuk menggantikan KKM konvensional menjadi KKM yang sesuai dengan protokol kesehatan dalam mencegah covid 19.

Panitia KKM Unbaja terus berinovasi dalam mencari jalan keluar untuk melaksanakan KKM yang sesuai protokol kesehatan tetapi tetap melaksanakan kegiatan pengabdian kepada masyarakat. Panitia mendapatkan ide program kreativitas mahasiswa PKM yang dilaksanakan oleh Kementerian Pendidikan dan Kebudayaan (Kemendikbud) menjadi bahan ide dalam pelaksanaan KKM 2020. PKM mengintegrasikan kegiatan pendidikan, penelitian dan pengabdian kepada masyarakat (Putri et al., 2018). Peserta yang mengikuti PKM Kemendikbud 
adalah mahasiswa aktif dari berbagai universitas. Program kreativitas mahasiswa (PKM) memiliki berbagai bidang kegiatan diantaranya program penelitian biasa disebut PKM penelitian, program pemberdayaan masyarakat biasa disebut PKM pengabdian masyarakat dan program wirausaha yang berbasis usaha yang unik biasa disebut PKM kewirausahaan. Program kreativitas mahasiswa adalah program yang dilakukan dengan proses pengajuan ide melalui proposal, proses pelaksanaan kegiatan dan proses laporan kegiatan. Proses pengajuan program PKM adalah menuangkan ide ke dalam proposal PKM yang berisikan ide baru atau jawaban dari permasalahan yang ada di masyarakat. Pembuatan proposal PKM melalui proses penggalian ide oleh peserta PKM dengan menelaah permasalahan yang terjadi di masyarakat. Peserta PKM mencari penyelesaian yang paling sesuai dengan mencari pengetahuan atau menggunakan teknologi terbarukan. Proses terakhir dalam pembuatan proposal adalah menuangkan ide dalam tulisan yang berbentuk proposal lalu dikirim kepada panitia PKM. Kegiatan PKM dalam proses pembuatan proposal PKM ini mirip dengan KKM yaitu menelaah permasalahan di masyarakat, merumuskan solusi dari berbagai sumber pengetahuan lalu membuat rancangan pelaksanaan program. Karakteristik umum PKM adalah mengembangkan kemampuan creative thingking dan high order thingking skils melalui implementasi pendidikan/pengajaran, penelitian/pengembangan dan pengabdian kepada masyarakat (Kemahasiswaan, 2019).

Berawal dari ide PKM inilah KKM 2020 pelaksanaannya menjadi KKM PKM. KKM PKM adalah kuliah kerja mahasiswa berbasis proposal program kreativitas mahasiswa. KKM PKM dilaksanakan oleh peserta dengan beberapa target luaran yang diberikan oleh panitia. Luaran yang harus dilaksanakan oleh peserta KKM antara lain membuat proposal PKM dengan proses dari menelaah masalah, mencari solusi, dan pembuatan proposal pelaksanaan kegiatan. Peserta KKM PKM diimbau tidak membaur dengan masyarakat dalam proses KKM. Sehingga KKM PKM dapat menggantikan peran KKM konvensional yaitu turut andil dalam penyelesaian permasalahan yang ada di masyarakat dan sesuai aturan PSBB.

KKM PKM menjadikan hal baru yaitu KKM dengan tidak membaur dengan masyarakat dan KKM berbasis PKM. Hal yang baru ini dirasakan oleh panitia KKM, mahasiswa peserta KKM dan dosen sebagai pendamping mahasiswa. Pelaksanaan KKM PKM perlu dikaji untuk mendapatkan informasi yang dapat digunakan di kemudian hari sehingga studi ini dilaksanakan. Penelitian ini menggali informasi KKM PKM dari segi tugas kelompok, tugas pribadi, dosen pendamping lapangan dan respon peserta terhadap KKM PKM. 


\section{METODE}

Penelitian ini dilakukan melalui beberapa tahapan. Pertama, penelitian dilakukan pada saat KKM PKM sedang berlangsung. Peneliti mengobservasi jalannya kegiatan KKM PKM dengan tujuan untuk mendapatkan informasi KKM PKM yang dijalankan. Informasi ini digunakan sebagai dasar dalam melakukan penelitian. Kedua, pembuatan kuesioner untuk pengambilan informasi. Kuesioner yang diberikan kepada peserta KKM PKM untuk mencari tahu terkait tugas kelompok, tugas pribadi, dosen pendamping lapangan dan respon peserta terhadap KKM PKM. Kuesioner terdiri dari 19 pertanyaan yang diisi melalui google form. Kuesioner diberikan kepada peserta KKM PKM setelah kegiatan selesai dilaksanakan. Ketiga, menganalisis hasil kuisioner.

\section{HASIL DAN PEMBAHASAN}

\section{Tahap Awal}

Penelitian ini diawali dari persiapan kegiatan KKM PKM. KKM PKM merupakan hal yang baru sehingga dosen pembimbing lapangan (DPL) belum memahami materi yang akan dibimbing. Panitia KKM PKM memberikan petunjuk teknis pelaksanaan. Panitia KKM PKM juga memberikan arahan dalam pembuatan proposal PKM dan tak lupa panitia mengingatkan aturan yang berlaku terkait protocol kesehatan.

Pelaksanaan KKM PKM diawali dengan pembagian kelompok dan pembukaan KKM PKM secara daring. Peserta intensif melakukan diskusi di masing-masing kelompok lalu mendiskusikannya dengan dosen pembimbing. Peserta KKM PKM mendapatkan tugas individu, kelompok PKM dan tugas kelompok besar. Pertama, tugas individu yang harus dilakukan mahasiswa adalah membuat konten yang di unggah pada media online atau menuliskan di media massa. Pengunggahan ke media online dengan cara memilih dua media social dari tiga media sosial yang ditunjuk yaitu youtube, instagram atau facebook. Tugas individu ini harus mendapatkan lebih dari 421 like dan mendapatkan lebih dari 100 comment atau share (LP3M, 2020). Jika peserta memilih untuk membuat konten pada media massa maka hanya perlu membuat satu konten saja.

Kedua, peserta KKM PKM juga mendapat tugas kelompok PKM. Kelompok besar KKM dengan pendamping satu DPL akan dibagi menjadi 3 atau lebih kelompok kecil (kelompok PKM). Kelompok PKM inilah yang akan membuat satu proposal PKM dengan bimbingan DPL. Proses pembuatan proposal PKM diawali dari penggalian permasalahan. Permasalahan diambil dari permasalahan umum yang sedang terjadi ataupun menganalisis permasalahan atau potensi di suatu daerah. Setelah mendapatkan masalah/potensi selanjutnya kelompok PKM mencari 
penyelesaian/pemanfaatan potensi dan mencari cara untuk menjalankan ide. Gagasan dan cara pelaksanaan tersebut dituliskan di proposal dengan format dan aturan yang sudah ditentukan. Peran DPL pada proses pembuatan proposal PKM adalah mendampingi dalam penggalian ide, mendampingi dalam pencarian jawaban dari permasalahan/potensi dan sebagai pendamping dalam pembuatan proposal.

Ketiga, tugas kelompok KKM atau kelompok besar dengan satu pendamping (DPL). Kelompok KKM PKM merupakan kelompok yang dibagi oleh panitia. Kelompok ini menjalankan KKM PKM secara bersama-sama dari mulai perencanaan kegiatan KKM, pelaksanaan kegiatan KKM dan pelaporan kegiatan KKM. Kelompok ini harus membuat struktur organisasi kelompok sehingga mudah dalam mengorganisasi dan dalam pelaporan. Tugas yang dimiliki kelompok besar adalah mengorganisasi jalannya KKM PKM pada kelompok dan menjalankan tugas akhir yaitu membuat laporan kegiatan.

\section{Tugas Kelompok KKM PKM}

Kelompok besar (KKM PKM) dibagi menjadi kelompok kecil (PKM). Kelompok PKM memiliki tugas untuk membuat proposal kegiatan PKM. Penilaian peserta KKM terhadap tugas pembuatan proposal PKM antara lain ketercapaian program dan nilai terhadap konten dari proposal. Hasil kuesioner Nilai yang anda berikan kepada kelompok anda terkait ketercapaian program sesuai dengan rencana adalah seperti gambar 1 berikut.

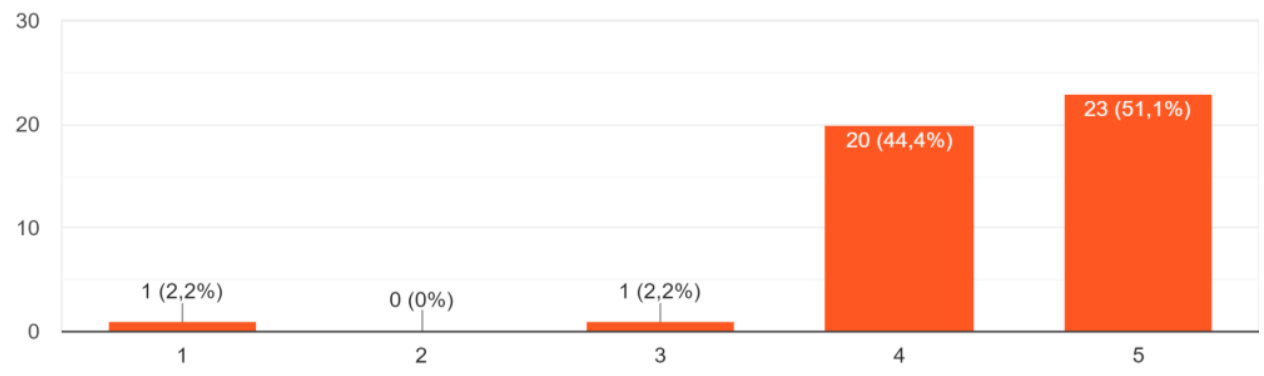

\section{Gambar 1. Nilai yang Diberikan Kepada Kelompok}

Respon sangat buruk mendapat $2.2 \%$, buruk mendapat $0 \%$, respon pertengahan mendapat $2.2 \%$, respon baik $44.4 \%$ dan respon sangat baik $51.1 \%$. Rata-rata dari respon mahasiswa adalah 4,4 dan mengindikasikan bahwa ketercapaian program KKM adalah baik. 


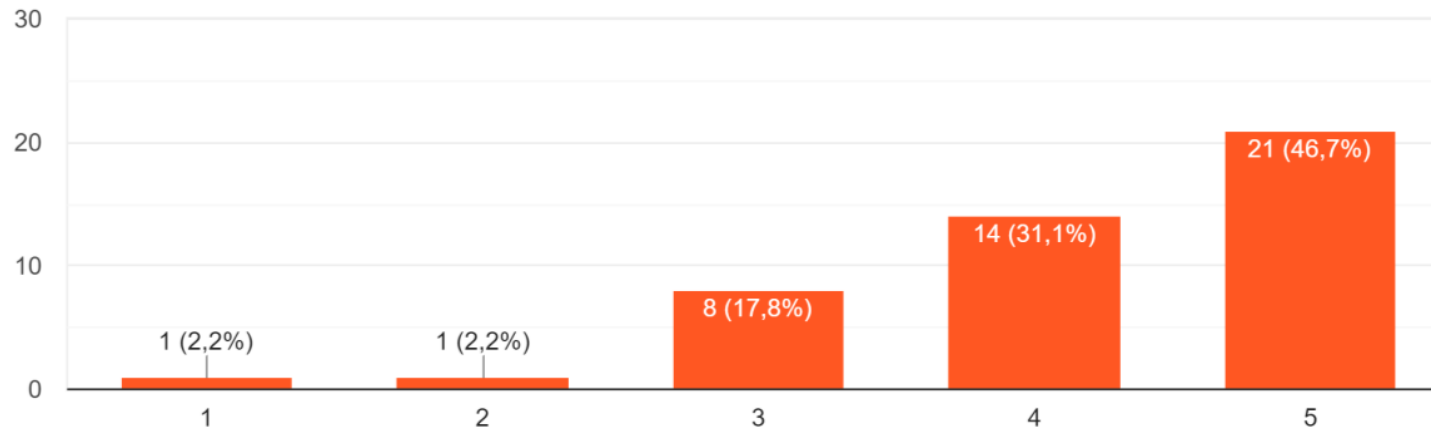

\section{Gambar 2 Nilai Proposal PKM}

Hasil kuesioner dari Nilai proposal PKM anda dalam keterbaruan, tantangan intelektual, dan relevansi dengan pengembangan ilmu pengetahuan, teknologi dan kebutuhan masyarakat cukup baik. Respon sangat buruk mendapat nilai $2.2 \%$, respon buruk mendapat $2.2 \%$, respon pertengahan pendapat $17.8 \%$, respon baik mendapat $31.1 \%$ dan respon sangat baik mendapat nilai $46.7 \%$. Respon mahasiswa terhadap tugas kelompoknya mendapat nilai rata-rata 4,17 dapat disimpulkan baik.

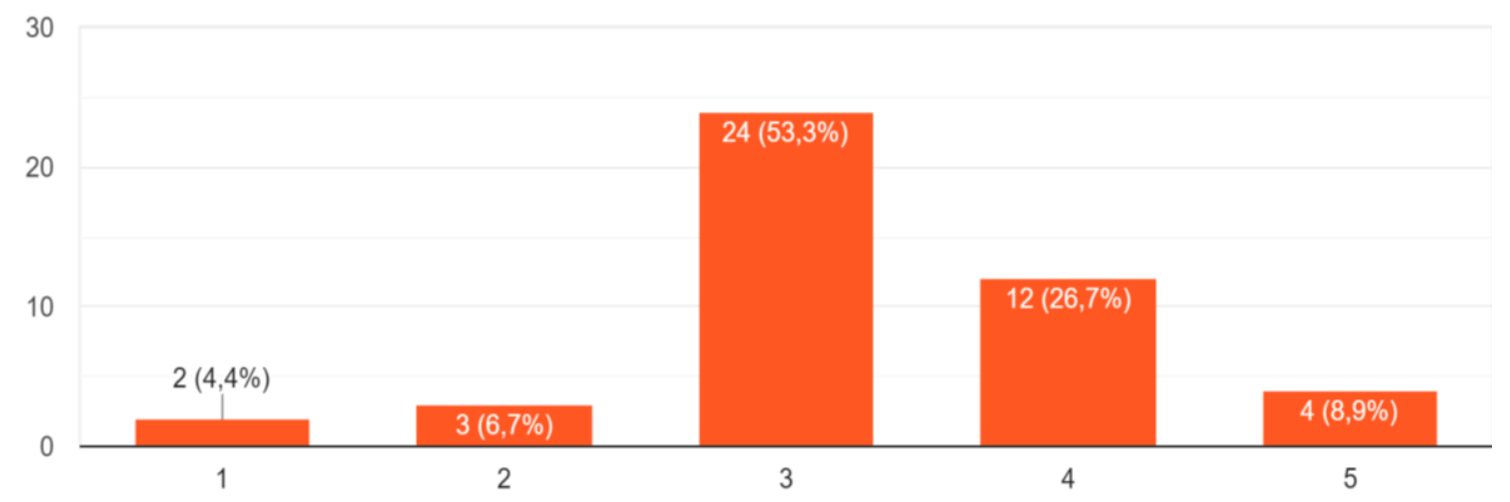

Gambar 3 Nilai Tugas Proposal Terlalu Mudah

Respon terhadap tugas pembuatan proposal PKM terlalu mudah dapat dilihat pada gambar 3 berikut. hasil respon sangat mudah mendapat $4.4 \%$, respon mudah mendapat $6.7 \%$, respon pertengahan mendapat $53.3 \%$, respon sulit mendapat $26.7 \%$ dan sangat sulit mendapat $8.9 \%$. Kita melihat diagram pada gambar 3 di atas kita dapat melihat puncak berada di tengah dan condong ke arah sulit dengan nilai rata-rata 3,29 sehingga kita menyimpulkan bahwa tugas pembuatan proposal PKM adalah antara pertengahan ke sulit.

Kesimpulan dari tugas kelompok KKM PKM sebagai berikut pertama, ketercapaian program kelompok KKM PKM adalah tercapai dengan baik. Kedua, nilai proposal PKM yang telah dibuat kelompok kecil mendapatkan rata-rata respon 4,17 atau baik. Tugas pembuatan 
proposal PKM mendapat rata-rata nilai 3,29 atau pertengahan kearah sulit. Tugas kelompok kecil secara umum mendapatkan respon yang baik. Saran untuk tugas kelompok kecil adalah perlu ditambahkan tugas yang lebih bervariatif.

\section{Tugas Individu}

Tugas individu yang diemban oleh peserta KKM didasari dari luaran KKM PKM pada panduan teknis. Tugas ini dibagi menjadi dua pilihan pertama publikasi pada media sosial. Mahasiswa memilih dua media sosial dari tiga media sosial yang ditunjuk sebagai tempat untuk publikasi. Mahasiswa dalam mempublikasikan kegiatan harus mendapatkan minimal 421 like dan minimal mendapatkan 100 comment atau share. Hasil dari kuesioner Media sosial apa yang anda gunakan untuk meng-share kegiatan PKM dapat dilihat pada gambar 4 berikut.

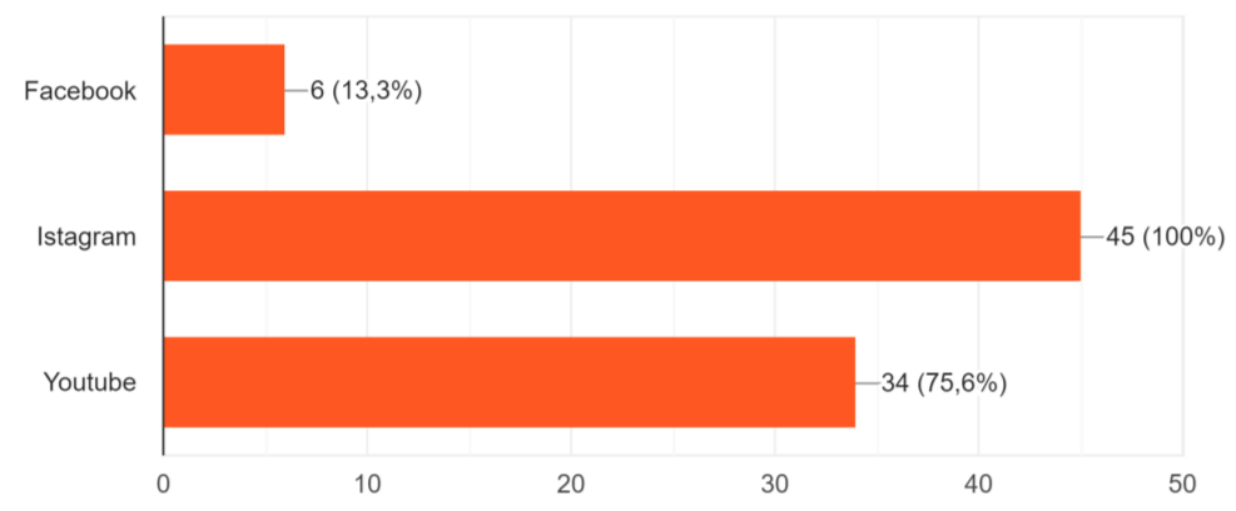

\section{Gambar 4 Media Sosial yang digunakan}

Media sosial yang digunakan oleh peserta KKM PKM sebagai berikut: media sosial instagram mendapat $100 \%$, media sosial youtube mendapat $75 \%$ dan media sosial facebook mendapat $13.3 \%$. Penggunaan media sosial oleh peserta KKM $100 \%$ memilih instagram dan pemilihan media sosial yang kedua antara youtube dan facebook. Hasil kuesioner ini mendapatkan informasi bahwa peminat media sosial facebook paling sedikit dibanding instagram dan youtube. 


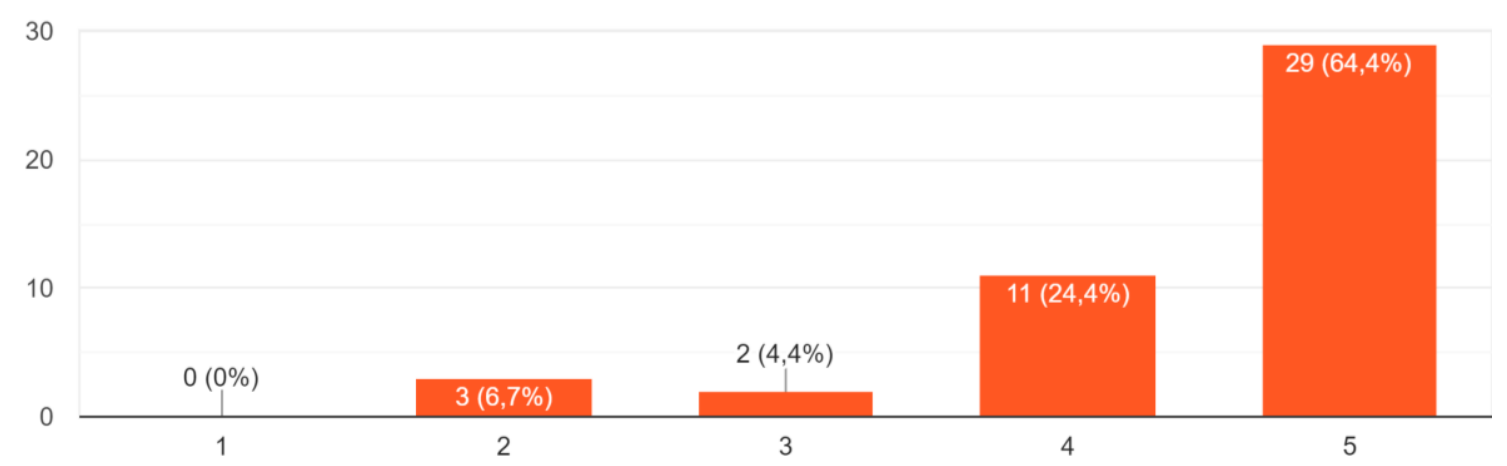

Gambar 5 Kesesuaian Konten dengan Tema PKM

Kuesioner berikutnya adalah mencari informasi terkait kesesuaian konten yang diunggah dengan tema KKM. Hasil dari Kesesuaian konten dengan tema KKM dapat dilihat pada gambar 5 berikut. Sangat tidak sesuai mendapat $0 \%$, tidak sesuai mendapatkan $6.7 \%$, pertengahan mendapat $4.4 \%$, sesuai mendapat $24.4 \%$ dan sangat sesuai mendapat $64.4 \%$. Jika kita memandang gambar 5 di atas maka kita dapat melihat hasil respon mengarah ke sangat sesuai. Hasil rata-rata adalah 4,46 dan mengindikasikan peserta condong untuk berusaha mengunggah konten sesuai tema KKM PKM.

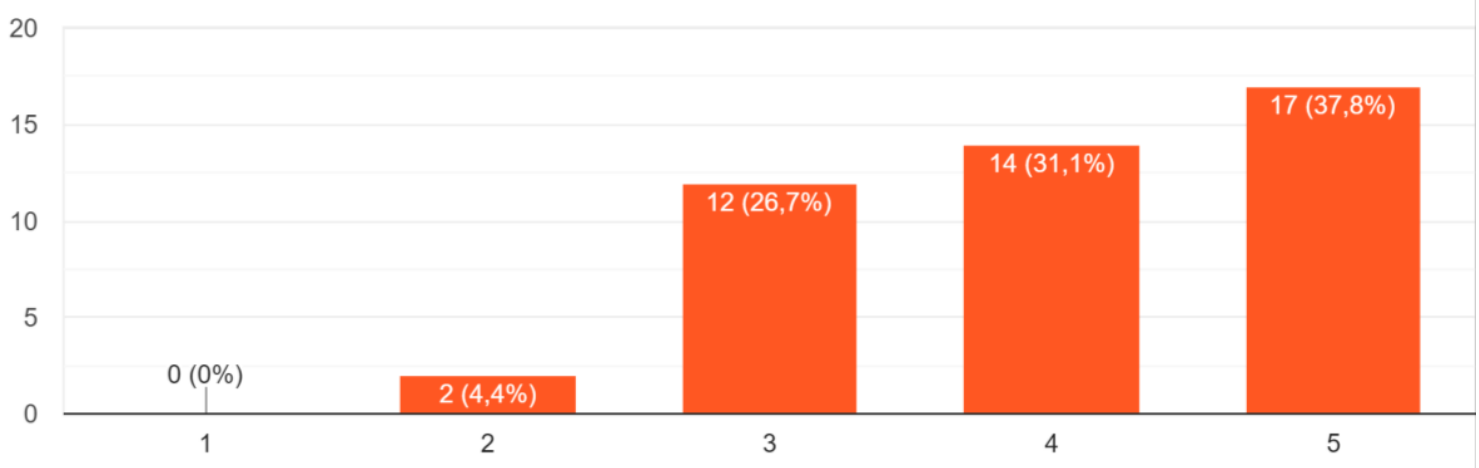

Gambar 6 Kualitas Konten Unggahan

Kuesioner selanjutnya sesuai dengan petunjuk dari panitia KKM PKM yang tertuang dalam panduan teknis yaitu konten unggahan memperhatikan kualitas. Hasil dari kuesioner Kualitas gambar/video sudah baik. sangat tidak berkualitas mendapat $0 \%$, tidak berkualitas mendapat $4.4 \%$, pertengahan mendapat $26.7 \%$, berkualitas mendapat $31.1 \%$ dan sangat berkualitas $37.8 \%$. Jika kita memandang gambar 6 di atas kita dapat melihat respon siswa menuju sangat berkualitas. Rata-rata yang didapat adalah 4,02 sehingga mengindikasikan peserta KKM mengunggah konten yang berkualitas dan berusaha memiliki kualitas yang lebih baik. 


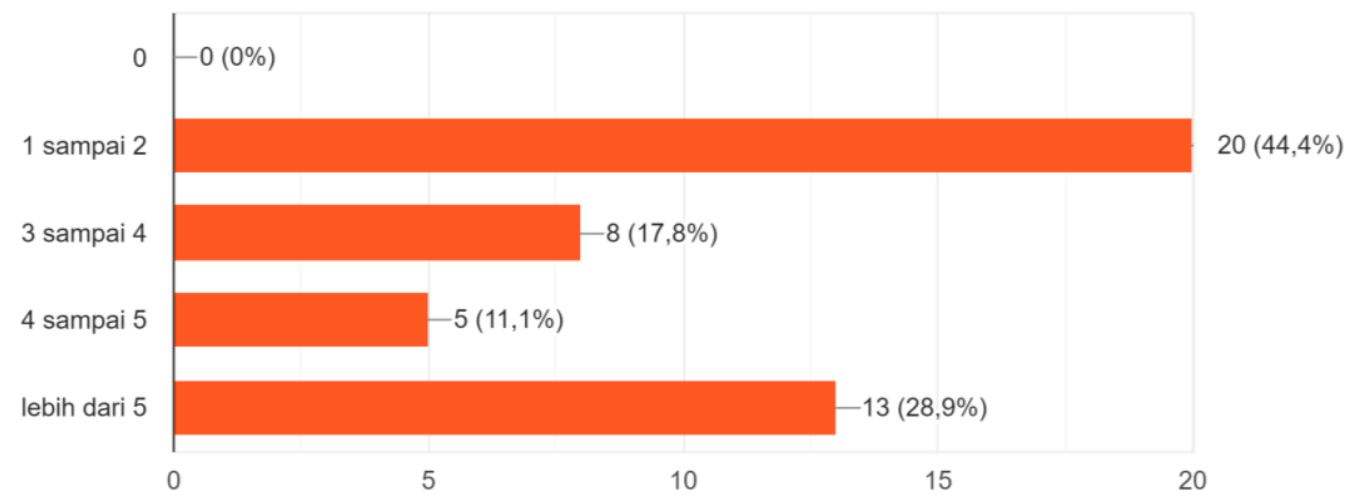

Gambar 7 Jumlah Konten Unggahan

Kuesioner selanjutnya Berapa banyak publikasi kegiatan KKM di media sosial. hasil dari kuesioner tersebut adalah 0 mendapat $0 \%, 1$ sampai 2 mendapat 44,4\%, 3 sampai 4 mendapat $17,8 \%$, 4 sampai 5 mendapat $11,1 \%$ dan lebih dari 5 sebanyak 28,9\%. Jika kita melihat grafik maka paling banyak mengunggah konten adalah sebanyak satu sampai dua konten.

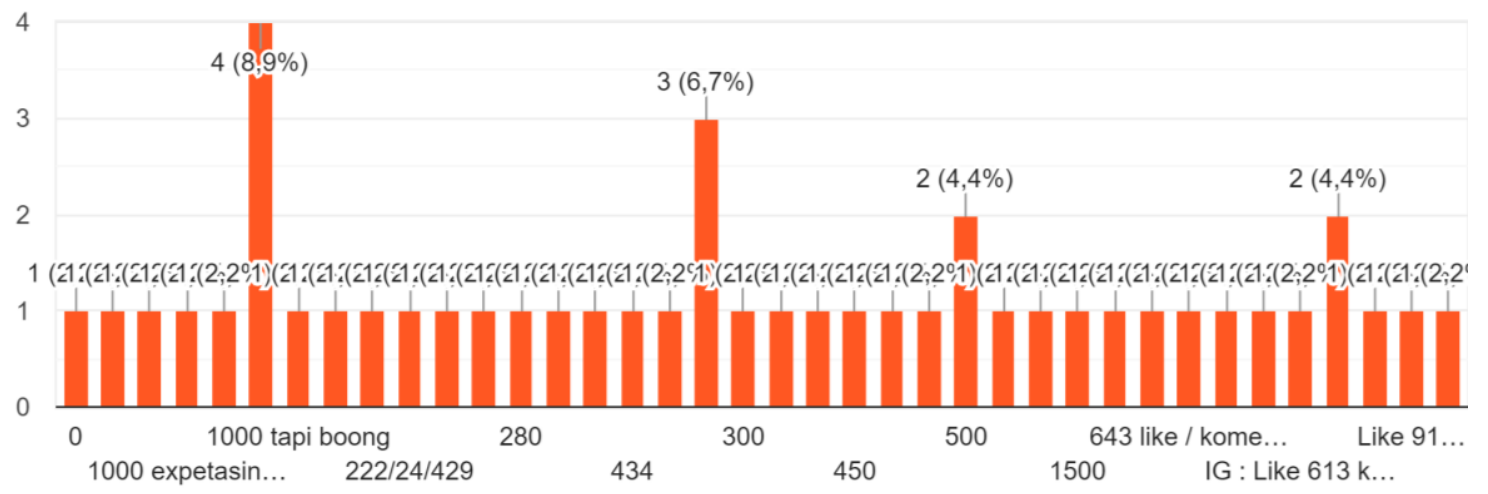

Gambar 8 Jumlah Like yang Diperoleh

Kuesioner selanjutnya Berapa like atau share atau komentar terbanyak dari postingan kegiatan KKM anda. hasil dari like/share/komen paling sedikit adalah 0 sebanyak 2,2\%, kurang dari 421 like adalah 22,2\% dan melebihi target 421 like adalah 75,6\%. Kesimpulan dari hasil publikasi sebagian besar peserta KKM sesuai target yaitu mendapatkan like lebih dari 421 . 


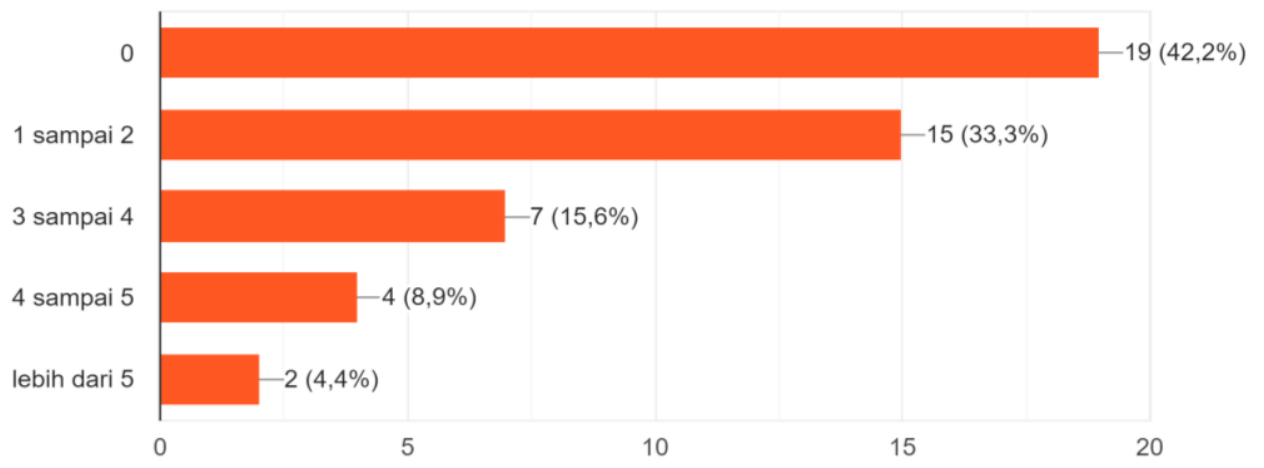

Gambar 9 Jumlah Konten yang Diunggah diMmedia Masa

Kuesioner selanjutnya Berapa banyak publikasi kegiatan KKM di media masa. hasil kuesioner menunjukan bahwa sebanyak 0 adalah 42\%, sebanyak 1 sampai 2 adalah 33,3\%, sebanyak 3 sampai 4 adalah 15,6\%, sebanyak 4 sampai 5 adalah 8,9\% dan lebih dari 5 adalah 4,4\%. Banyak mahasiswa yang tidak mempublikasikan di media masa.

Kesimpulan dari tugas individu sebagai berikut, pertama yang paling banyak digunakan mahasiswa dalam mengunggah publikasi adalah instagram. Kedua, konten yang diunggah ke media sosial sebagian besar sesuai tema KKM PKM. Ketiga, konten yang diunggah ke media sosial memiliki kualitas yang baik dan sebagian besar sudah sangat berkualitas. Keempat, peserta paling banyak mengunggah konten sebanyak satu atau dua kali. Kelima, sebagian besar atau sebanyak 75,6\% peserta KKM sudah mencapai target yaitu mendapat like sebanyak 421 . Keenam, sebagian besar peserta KKM tidak mempublikasikan di media masa. Tugas individu dari peserta KKM PKM sebagian besar sudah mencapai target.

\section{Tugas DPL}

Dosen pembimbing lapangan (DPL) memiliki tugas antara lain: membimbing peserta KKM PKM secara intensif, membimbing pembuatan proposal PKM, membimbing peserta KKM PKM dalam pembuatan konten yang akan dipublikasikan dan DPL menyarankan mahasiswa untuk tidak terjun langsung ke lapangan. Hasil kuesioner DPL membimbing mahasiswa atau kelompok secara intensif sebagai berikut: sangat tidak intensif mendapat $4,4 \%$, tidak efektif mendapat $0 \%$, pertengahan mendapat $26,7 \%$, intensif mendapatkan $37,8 \%$ dan sangat intensif mendapatkan $31,1 \%$. rata-Rata dari respon siswa adalah 3,91 yaitu DPL membimbing intensif. 


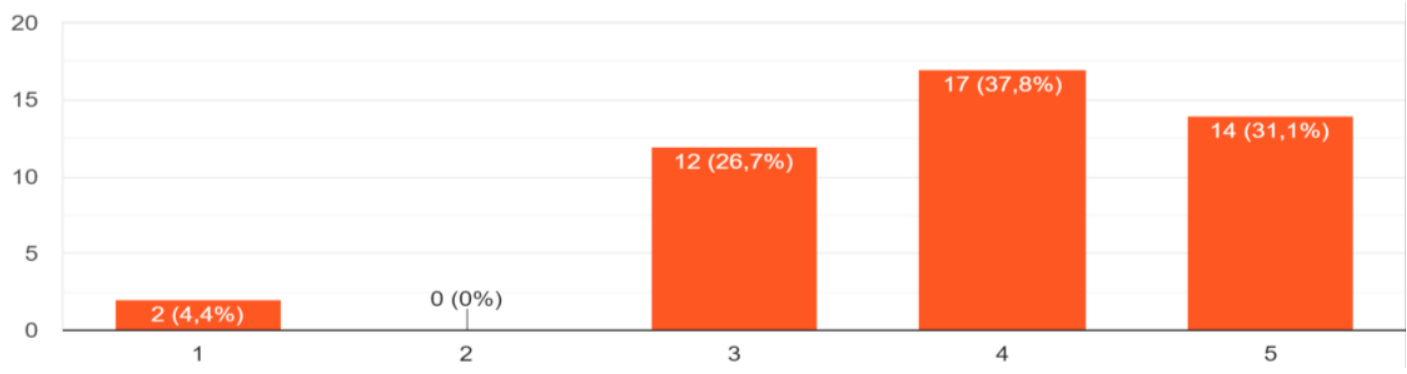

Gambar 10 Nilai DPL Membimbing Peserta

Kuesioner selanjutnya adalah dalam pembuatan proposal PKM, DPL membimbing dengan menelaah, memberikan komentar dan merekomendasikan perbaikan. Hasil dari kuesioner adalah sangat tidak membimbing 2,2\%, tidak membimbing 2,2\%, pertengahan $24,4 \%$, membimbing $24,4 \%$ dan sangat membimbing $46,7 \%$. Rata-rata dari hasil kuesioner adalah 4,10 yaitu dosen membimbing dengan efektif.

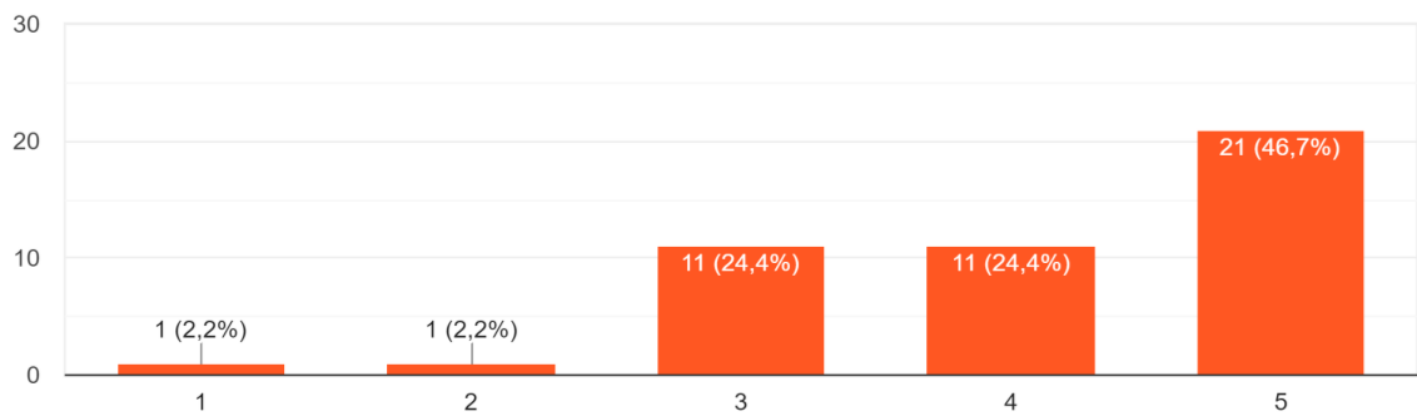

\section{Gambar 11 DPL Membimbing Pembuatan Proposal PKM}

Kuesioner selanjutnya adalah DPL membimbing mahasiswa dalam membuat konten yang akan diupload di media sosial atau media masa. Hasil dari kuesioner sangat tidak membimbing adalah $2,2 \%$, tidak membimbing adalah $4,4 \%$, pertengahan adalah $24,4 \%$, membimbing adalah $33,3 \%$ dan sangat membimbing adalah 35,6\%. Rata-rata skor dari kuesioner adalah 3,95 yaitu DPL membimbing. 


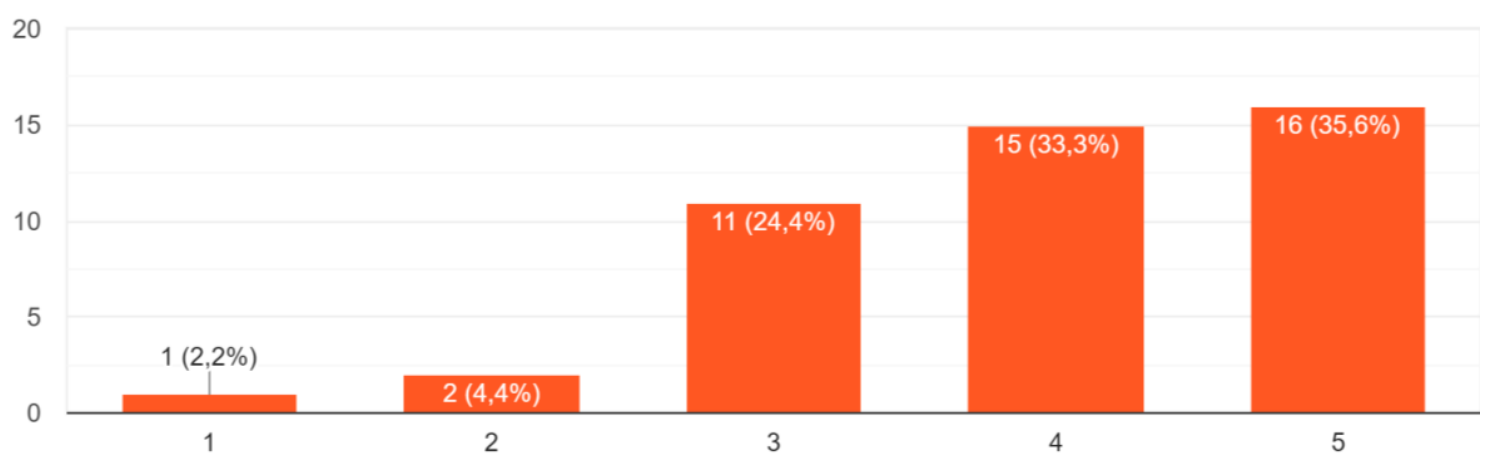

Gambar 12 DPL Membimbing Pembuatan Konten Unggahan

Kuesioner selanjutnya adalah DPL membimbing pembuatan tugas akhir. hasil dari respon peserta KKM adalah sangat tidak membimbing mendapat 2,2\%, tidak membimbing adalah $2,2 \%$, pertengahan $17,8 \%$, membimbing adalah $33,3 \%$ dan sangat membimbing adalah $44,4 \%$. Rata-rata dari respon peserta KKM adalah 4,15 atau membimbing.

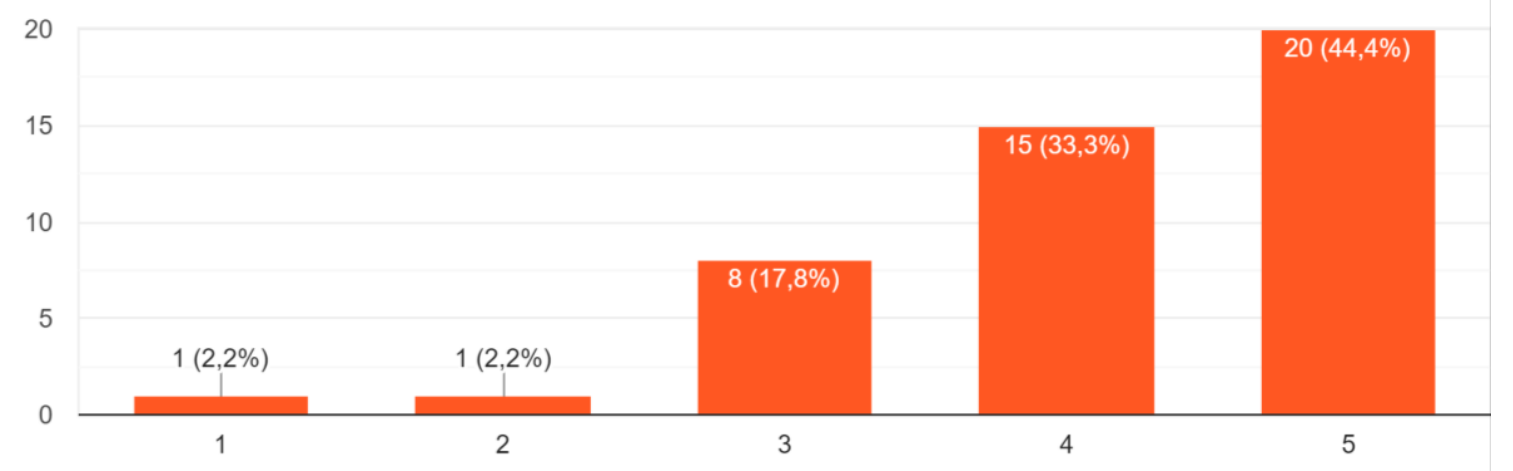

Gambar 13 DPL Membimbing Pembuatan Tugas Akhir

Kuesioner selanjutnya adalah DPL mengarahkan mahasiswa untuk terjun langsung ke lapangan untuk melaksanakan program KKM. Hasil respon peserta KKM adalah DPL mengarahkan terjun langsung mendapat $20 \%$ dan DPL mengarahkan tidak terjun langsung mendapat $80 \%$. Data ini menunjukan masih terdapat dosen yang menyarankan peserta KKM PKM untuk terjun langsung. 


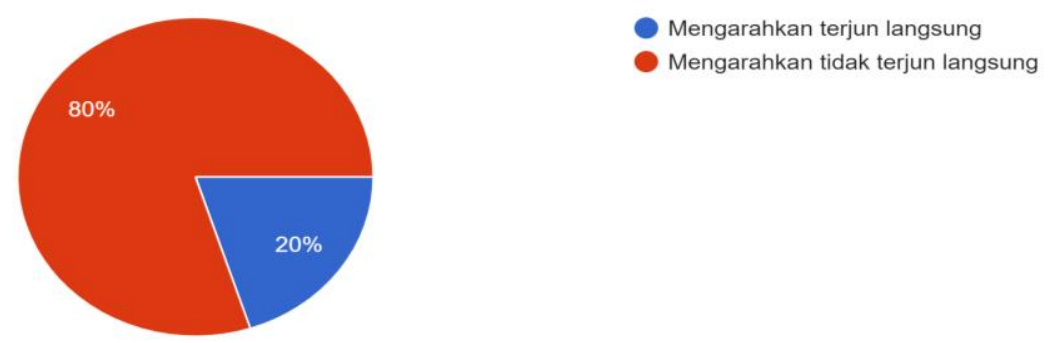

\section{Gambar 14 DPL Menyarankan Peserta Tidak Terjun ke Lapangan}

Simpulan dari tugas DPL antara lain DPL membimbing secara intensif, DPL membimbing peserta dalam pembuatan proposal PKM secara intensif, DPL membimbing dalam pembuatan konten yang akan dipublikasikan, DPL membimbing dalam pembuatan tugas akhir dan DPL menyarankan untuk tidak terjun langsung ke lapangan.

\section{Respon Peserta terhadap KKM PKM}

Bagian ini membahas respon dari peserta KKM PKM terkait kegiatan KKM PKM. kuesioner KKM PKM lebih disarankan di masa pandemic Covid 19 adalah respon sangat tidak disarankan mendapat 15,6\%, tidak disarankan mendapat 11,1\%, pertengahan mendapat 33,3\%, disarankan mendapat $15,6 \%$ dan sangat disarankan mendapat $24,4 \%$. Rata-rata dari skor respon peserta adalah 3,22 atau pertengahan karena respon peserta berpusat di pertengahan respon yang banyak terdapat pada sangat disarankan dan sangat tidak disarankan.

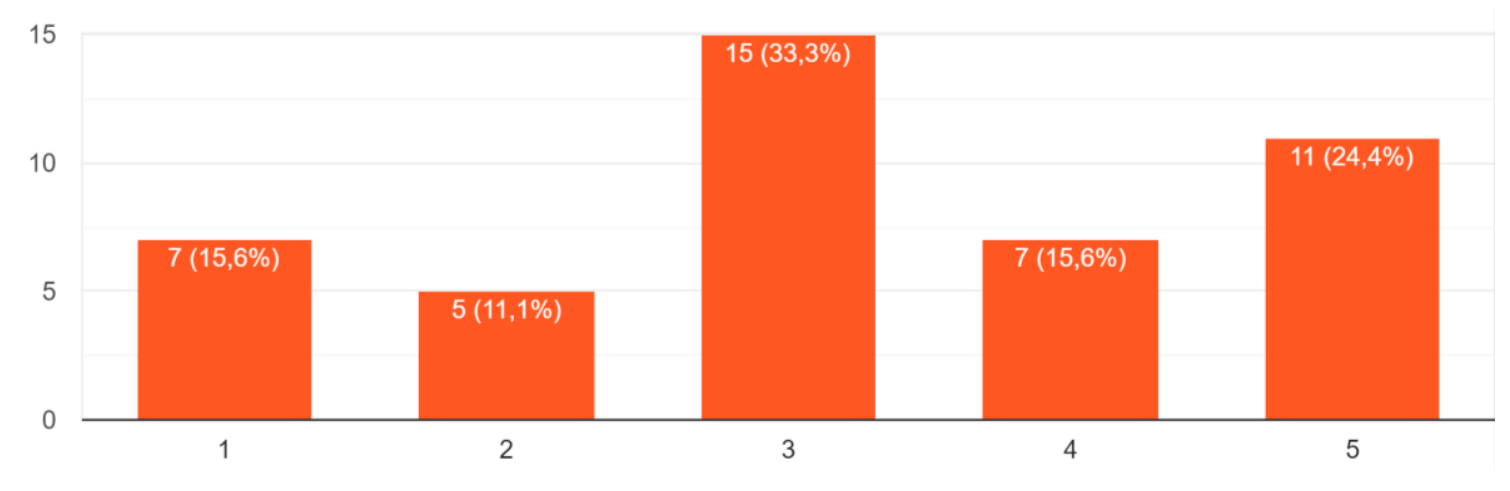

\section{Gambar 15 Saran Pelaksanaan KKM PKM di Masa Covid}

Kuesioner selanjutnya adalah Anda merasa menyesal mengikuti KKM PKM tahun akademik 2019/2020. Sangat menyesal mendapat 17,8\%, menyesal mendapat 4,4\%, pertengahan mendapat $37,8 \%$, puas mendapat $24,4 \%$ dan sangat puas mendapat $15,6 \%$. Ratarata dari skor adalah 3,16 atau mendekati puas. Respon peserta KKM seharusnya tidak ada yang menyesal dan minimal mendapat respon pertengahan. Terdapat peserta KKM PKM yang tidak puas terhadap program KKM PKM. 


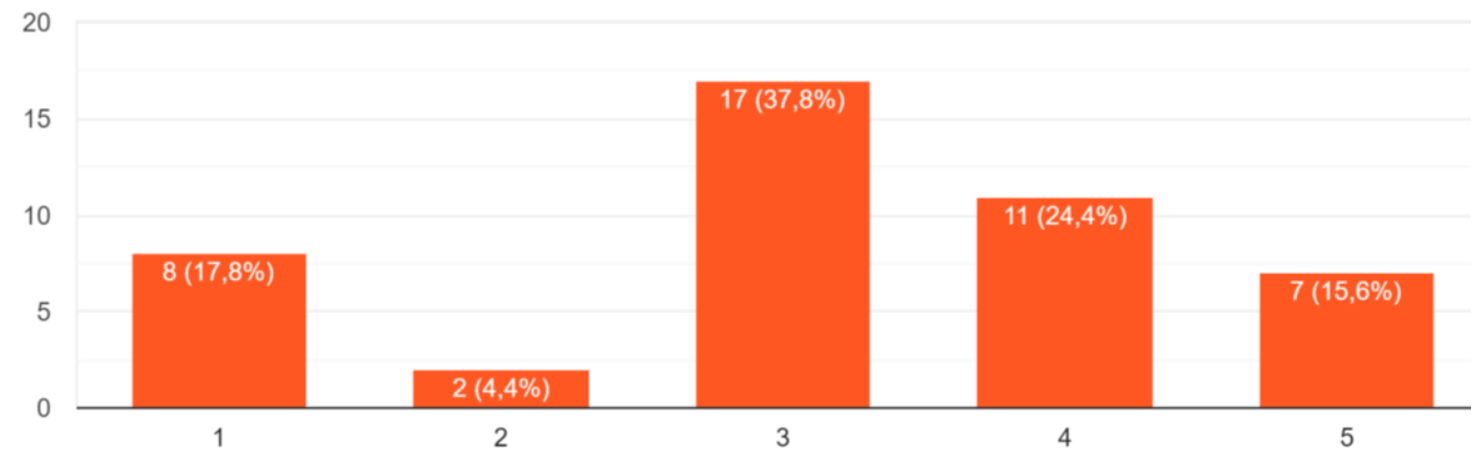

Gambar 16 Kepuasan Mengikuti KKM PKM

Kuesioner selanjutnya adalah Setelah aman dari Covid 19, anda menyarankan KKM PKM dibandingkan KKM biasa. hasil respon adalah sangat tidak menyarankan mendapat $24,4 \%$, tidak menyarankan mendapat $17,8 \%$, pertengahan mendapat $26,7 \%$, menyarankan mendapat $13,3 \%$ dan sangat menyarankan sebanyak 17,8\%. Rata-rata dari skor adalah 2,82 atau pertengahan.

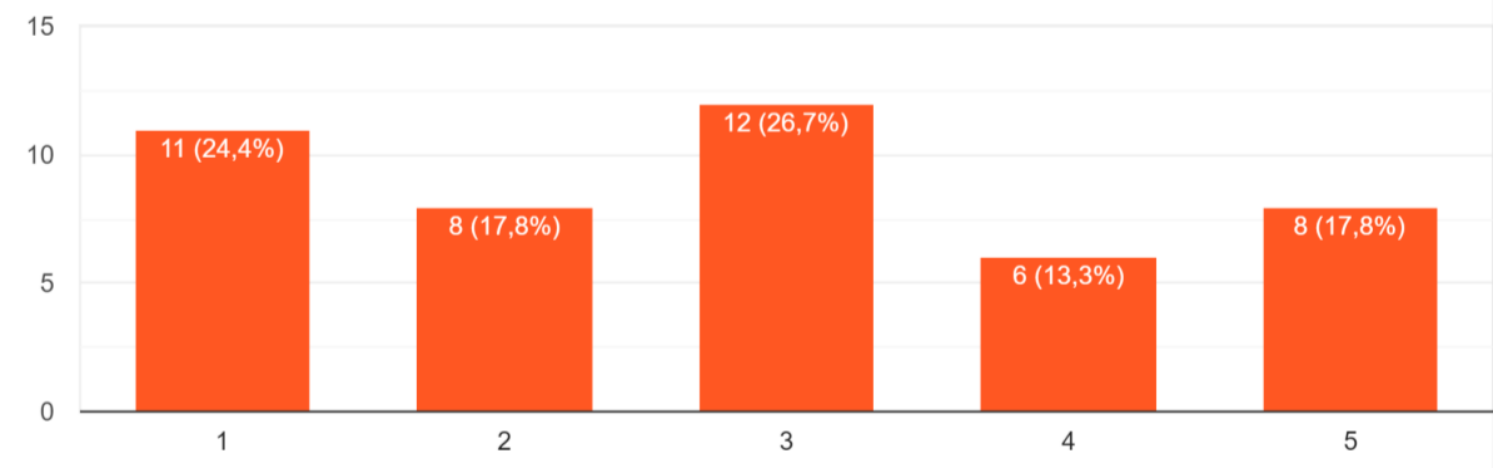

Gambar 17 Menyarankan KKM PKM disaat Aman dari Covid 19

Kuesioner selanjutnya adalah anda merasa KKM PKM lebih mudah diikuti dibanding KKM seperti biasanya. Sangat sulit mendapatkan $11,1 \%$, sulit mendapatkan 15,6\%, pertengahan mendapat $37,8 \%$, mudah mendapat $13,3 \%$ dan sangat mudah mendapat nilai $22,2 \%$. Dilihat dari kurva sebaran respon peserta KKM adalah normal yaitu condong ketengah. Rata-rata dari skor respon peserta kkm adalah 3,19 atau pertengahan. 


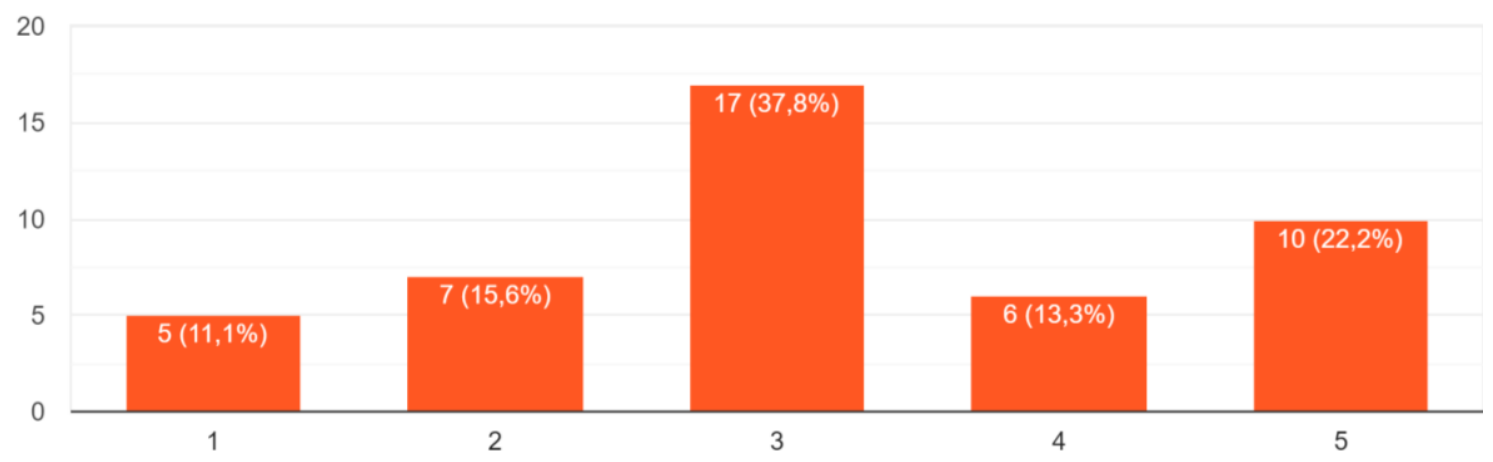

Gambar 18 Kemudahan KKM PKM

Pertanyaan selanjutnya adalah setelah melaksanakan KKM PKM, Anda merasa sudah berkontribusi dalam pengabdian masyarakat. Respon yang didapat adalah sangat tidak berkontribusi mendapat $4,4 \%$, tidak berkontribusi mendapat $11,1 \%$, pertengahan mendapat $28,9 \%$, berkontribusi mendapat $33,3 \%$ dan sangat berkontribusi mendapat $22,2 \%$. Rata-rata dari skor respon peserta didapat 3,58 atau berkontribusi.

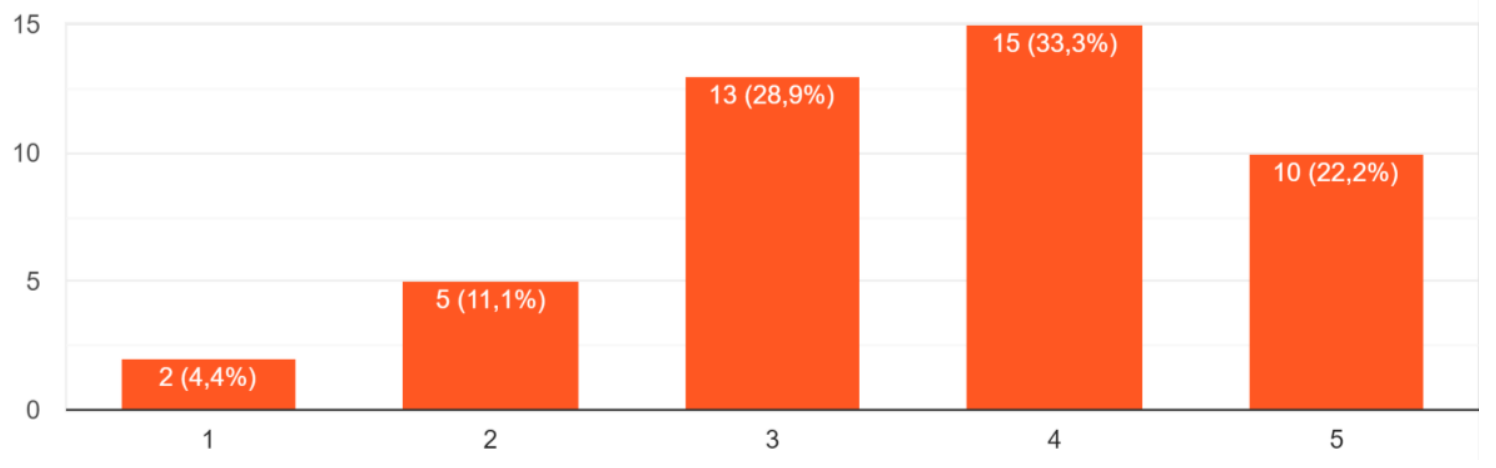

Gambar 19 Rasa Pengambdian Kepada Masyarakat

Kesimpulan dari respon mahasiswa terhadap KKM PKM adalah pertama, KKM PKM mendapat respon pertengahan dalam saran pelaksanaan KKM PKM. Kedua, terdapat 17,8\% sangat menyesal dan 4,4\% menyesal mengikuti KKM PKM yang mengindikasikan peserta kurang puas terhadap KKM PKM. Ketiga, saran pelaksanan KKM PKM setelah aman dari Covid 19 adalah mendapatkan respon pertengahan. Keempat, respon KKM PKM lebih mudah dibanding KKM biasa mendapat skor pertengahan atau KKM PKM memiliki tingkat kesulitan yang sebanding dengan KKM biasa. Kelima, perserta KKM PKM merasa sudah ikut bekontribusi dalam pengambidan kepada masyarakat melalui kegiatan KKM PKM. 


\section{KESIMPULAN DAN SARAN}

Hasil studi yang dilakukan mendapatkan beberapa kesimpulan. Pertama, tugas kelompok PKM mendapatkan respon yang baik tetapi memiliki tingkat kesulitan yang biasa. Tugas individu dari peserta KKM PKM sebagian besar sudah terlaksana dengan baik tetapi ada beberapa peserta yang tidak mencapai target. Dosen pendamping lapangan (DPL) secara umum sudah menjalankan tugas dengan baik yaitu ikut membimbing kelompok besar, membimbing kelompok PKM dan membimbing tugas individu tetapi masih terdapat respon negatif dari peserta KKM PKM terkait DPL. Respon peserta terhadap KKM PKM secara umum mendapatkan respon pertengahan atau sebanding dengan KKM PKM. Terdapat respon negatif dari peserta terkait kepuasan dalam melaksanakan KKM PKM.

Saran yang didapat dari hasil penelitian dan kesimpulan antara lain pertama, tugas perserta KKM PKM dibuat lebim menantang. Kedua, DPL lebih intensif dalam melaksanakan tugas dan membimbing peserta. Ketiga, KKM PKM 2020 dapat dijadikan bahan kajian dengan tujuan perbaikan sehingga peserta mendapatkan pengalaman berharga dalam melaksanakan KKM dan merasa puas.

\section{DAFTAR PUSTAKA}

Athena, A., Laelasari, E., \& Puspita, T. (2020). Pelaksanaan Disinfeksi Dalam Pencegahan Penularan Covid-19 Dan Potensi Risiko Terhadap Kesehatan Di Indonesia. Jurnal Ekologi Kesehatan, 19(1), 1-20. https://doi.org/10.22435/jek.v19i1.3146.

Kemahasiswaan, D. jendral pembelajaran dan. (2019). Buku Pedoman PKM 2020. Kementerian pendidikan dan kebudayaan.

LP3M. (2020). Panduan Teknis Pelaksanaan Kuliah Kerja Mahasiswa (KKM). Universitas Banten Jaya.

Perdana, A., Holilulloh, \& Nurmalisa, Y. (2013). Pengaruh Pelaksanaan Kuliah Kerja Nyata (KKN) terhadap Keterampilan Sosial Mahasiswa Program Studi PPKN Universita Lampung. Jurnal Kultur Demokrasi, 2(3), 1-22. http://jurnal.fkip.unila.ac.id/index.php/JKD/article/view/2145.

Putri, L. D., Repi, \& Soehardi, F. (2018). Pemberdayaan Mahasiswa Fakultas Teknik Dengan Program Kreatifitas Mahasiswa (Pkm). Dinamisia: Jurnal Pengabdian Kepada Masyarakat, 2(2), 135-141. https://doi.org/10.31849/dinamisia.v2i2.1184.

Renaldi, T., Teknik, J., Fakultas, E., \& Lampung, U. (2013). Nyata Universitas Lampung Berbasis Web. Jurnal Informatika dan Teknik Elektro Terapan, 1(3), 1-11.

$\mathrm{Su}, \mathrm{B} .$, \& Hu, Q. (2020). Research on improving the quality of online teaching based on big data under the COVID-19 coronavirus epidemic. Journal of Physics: Conference Series, 
1616(1). https://doi.org/10.1088/1742-6596/1616/1/012018.

Yuliana. (2020). Corona virus diseases (Covid-19): Sebuah tinjauan literatur. Wellness and Healthymagazine, 2(February), 124-137. https://doi.org/10.2307/j.ctvzxxb18.12. 